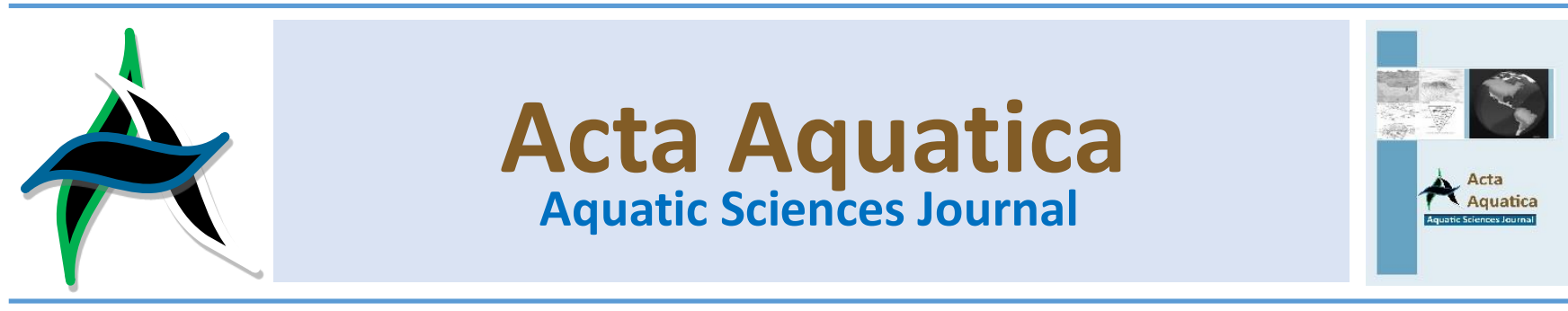

\title{
A new goatfish species of the genus Upeneus (Mullidae) in the Gulf of Antalya
}

\author{
Mehmet Gökoğlu ${ }^{\mathrm{a}, *}$ \\ ${ }^{a}$ Faculty of Fisheries, Akdeniz University
}

\begin{abstract}
During the night diving in the Gulf of Antalya, a different type of mullidae member was seen. This fish was determined that this species is Upeneus tragula. There are two species of fish belonging to the Upeneus genus Mullidaein the Mediterranean. With the addition of Upeneus tragula to these fishes, the number of Upeneus genus in the Mediterranean has increased to three.
\end{abstract}

Keywords: Upeneus tragula; Gulf of Antalya; Coast of Turkey; Mediterranean

\section{Introduction}

Goat fishes from Mullidae family are known and commercially important fish all over the world (Pavlov and Emel Yanova 2018). There are 6 species belonging to this family in the Mediterranean. Two of these species are native and four are exotic species. Upeneus moluccensis, $U$. pori and Parupeneus forskalli are species of the Red Sea origin (Golani et al. 2006: Barich et al. 2013, Deidun et al. 2018). Pseudupeneus prayensis is of eastern Atlantic origin (Mercader 2002; Azzouz et al., 2011). The members of this family are characterized by two barbels.

The Gulf of Antalya, located in the sea of Levant, is one of the regions where lessepsian migrants are most common (Gökoğlu 2016). Until now, the number of lessepsian fish species detected in the Gulf of Antalya has reached 60 . Mullidae family members are also included in this species.

The number of species of Mullidae family found in the Gulf of Antalya is five. These fishes are $M$. barbatus, $M$. surmuletus, U. pori, $U$. moluccensis and Parupeneus forskalli (Barich et al., 2013). The species in the Upeneus genus of the Mullidae family are species that mix the two-barbels and sediment in the sandy, sandymuddy areas of the coastal areas. They feed on organisms such as worms, crustacea and polyket found in the sediment (Golani et al. 2006).

During the night diving in the Gulf of Antalya, a different type of mullidae member was seen. In this study, it was determined that this species is Upeneus tragula.

\section{Materials and methods}

During the night dives on the coast of Tekirova in the Gulf of Antalya (Figure 1), a different fish species was identified.

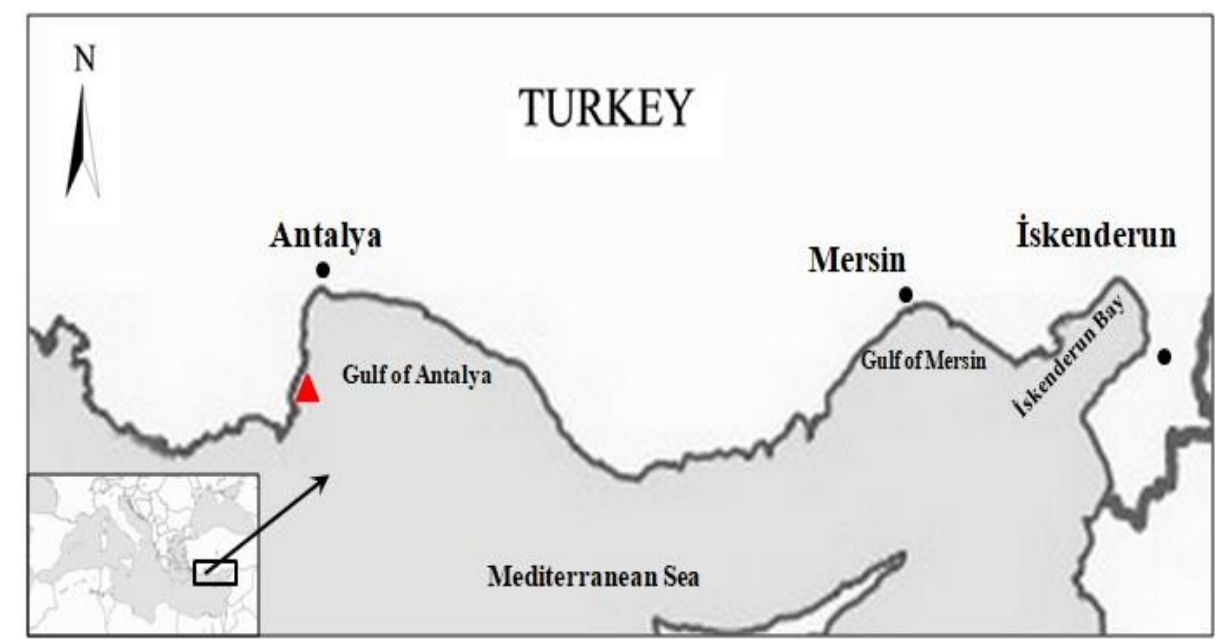

Figure 1. Sampling location.
* Corresponding author: Faculty of Fisheries, Akdeniz University, 07058. Antalya, Turkey. Tel: +905358554167

e-mail: gokoglu@akdeniz.edu.tr

doi: http://doi.org/10.29103/aa.v5i2.796
The video footage of this fish was taken during their dives. During the dives, the video images of this fish were taken. The Canon Power Shot G7 X Mark II camera has been used for video shooting. Video footage was shot by diver Mustafa Karakoç. The fish is displayed at a depthh of 3-4 m on sandy 
ground. Video images of the fish was watched on the computer and the species was identified.

\section{Result and discussion}

At night dives, the fish seen on sandy ground at Tekirova coast in the Gulf of Antalya was identified as a young Upeneus tragula (Figure 2). This species, which belongs to the Mullidae family Upeneus genus, ranges from Eastern Indian Ocean to Western Pacific and Andaman Islands to Australia and to Japan and New Caledonia (Randal and Kulbicki, 2006).

We counted the fin rays of the fish. They have been found, dorsal fin rays VIII, 9; anal fin rays I, 7; pelvic fin rays I, 5 . Head and body blueish, dorsal and upper side with dark spots forming irregular vertical lines; below head and body white, flecked with small dark spots barbels white; both dorsal fins dark -brown with a few small spots; pelvic and anal fins with dark spot; lobes of caudal fin with diagonal black and dark band (Randal and Kulbicki 2006; Yeob Kim et al., 2013).

It was identified as young Upeneus tragula based on some morphological characters; both lobes of caudal fin with dark bands, body with many blackish dots and counts (Randall, 2001; Yeob Kim et al. 2013). This fish found over sandy and muddy bottoms, may be found near corals and has been known to enter the lower parts of the rivers. Usually it found solitary and depths of up to $40 \mathrm{~m}$ (Yeob Kim et al., 2013).

There are two species of fish belonging to the Upeneus genus Mullidae in the Mediterranean. These two species are of the Red Sea origin (Golani et al., 2006). These species are fish that are distributed in sandy, sandy muddy bottoms of coastal areas. Both species are among the important commercial species in the troll fishing of the Gulf of Antalya (Yeşilçimen and Kuşat, 2011). With the addition of Upeneus tragula to these fishes, the number of Upeneus genus in the Mediterranean has increased to three.

Many fish species passing through the Mediterranean Sea through the Red Sea are not evaluated economically. When these fish are caught in fishing gear, the fishermen spend an extra labor and time. It also harms fishing gear and equipment. $U$. tragula is one of the important commercial fish species of the Indo-pacific waters. species having economic value of the Mediterrranean. We determined its morphological characteristics of this species and newly added it to the Turkey fish fauna.

\section{Bibliografi}

Azzouz; K., Diatta, Y., Mansour, S., Boumaiza, M., Ben Amor, M.M., Capape, C., 2011. First record of the west African goatfish, Pseudupeneus prayensis (Actinopterygii: Perciformes: Mullidae), off the Tunisian coast (central Mediterranean). Acta Ichthyologica Et Piscatoria 41 (2): 133-136, DOI: 10.3750/AIP2011.41.2.10

Bariche; M., Bilecenoglu; M., Azzurro, E., 2013. Confirmed presence of the Red Sea goatfish Parupeneus forsskali (Fourmanoir \& Guézé, 1976) in the Mediterranean Sea. Biolnvasions Records, Vol. 2, Issue 2: 173-175

Deidun, A., Zava, B., Insacco, G., Corsini-Foka, M., 2018. First record of the Por's Goatfısh Upeneus pori (Actinopterygii Perciformes: Mullidae) from Italian waters (Western Ionian Sea). Acta Ichthyologica Et Piscatoria, 48 (1): 93 97

Golani, D., Öztürk, B., Başusta, N. (2006). Fishes of the Eastern Mediterranean. Turkish Marine Research Foundation, Istanbul, Turkey. Pub. Number: 24, pp. 259.

Gökoğlu, M., 2016. The Latest Visitors to Phaselis and the Fish not Consumed by the People of Phaselis. Phaselis Vol. II. 1-7

Mercader, L., 2002. First record of Pseudupeneus prayensis (Mullidae) in the Catalan Sea. Cybium: internationa journal of ichthyology 26(3):235-236

Pavlov, D.A., Emel Yanova, N.G., 2018. Variation of Freckled Goatfish Upeneus tragula (Mullidae): Color Morphs off Hon Thom (Gulf of Thailand, South China Sea). Journal of Ichthyology, Vol. 58, No. 3, pp. 371-381.

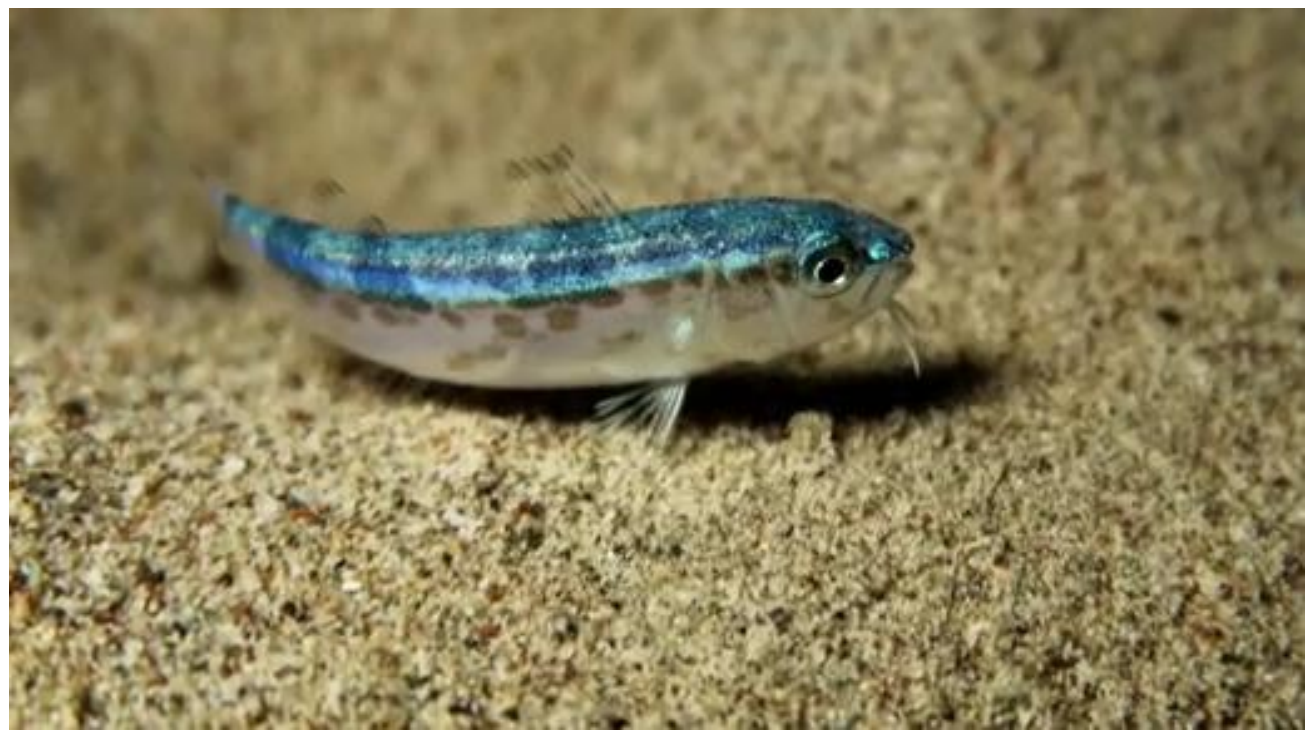

Figure 2. Upeneus tragula.

$U$. tragula which we identified a single individual for now, if it forms a certain population in the Mediterrranean such as other species of Upheneus genus, it will be among the fish
Randall, J.E. 2001. Mullidae. Goatfishes (surmullets). pp. 3175-3200. In: Carpenter, K.E. and V.H. Niem (eds.), FAO species identification guide for fishery purposes. The living marine resources of the Western Central Pacific. Vol. 5. Bony fishes part 3 (Menidae to Pomacentridae). Rome, FAO, pp. 2791-3380

Randal; J.E., Kulbicki, M., 2006. A Review of the Goatfishes of the Genus Upeneus (Perciformes: Mullidae) from New Caledonia and the Chesterfield Bank, with a New Species and Four New Records. Zoological Studies 45(3): 298-307

Yeob Kim, B., Jin Kim, M., Bok Song, C., 2013. First Record of the Freckled Goatfish, Upeneus tragula (Mullidae, 
Perciformes) from Korea. Korean Journal of Ichthyology, Vol. 25, No. 4, 244-248

Yeşilçimen, H.Ö., Kuşat, M., 2011. Monthly change of economic fish species caught by bottom trawl fishing from Antalya bay. Journal of Fisheries Sciences, 5(2): 115-121 